\title{
Özel ve Resmi Okullarda Görev Yapan Okul Öncesi ve Sınıf Öğretmenlerinin Yaratıcılık ve Tükenmişlik Düzeyleri Arasındaki İlişki
}

\author{
The Relationship Between Creativity and Burnout Levels of Preschool and Primary School Teachers
} Working in Private and Public Schools

\section{Duygu KOZAN ${ }^{1}$, Elvan ŞAHINN-ZETEROĞLU², Ayçin EMEKSEVER ${ }^{3}$}

\begin{abstract}
Öz
Öğretmenlerin, yaratıcı düşünmelerini geliştirmeleri, sorunlara yaratıcı çözümler bulmaları, sorunların yarattı̆ğ tükenmişlik durumuyla başa çıkmalarına bağlıdır. Bu çalışmanın amacı, özel ve resmi okullarda görev yapmakta olan okul öncesi ve sınıf öğretmenlerinin yaratıcılık ve tükenmişlik düzeyleri arasındaki ilişkiyi incelemektir. Çalışma, Bursa ili Nilüfer ilçesinde 2020-2021 eğitim-öğretim yllında özel ve resmi okullarda görev yapmakta olan toplam 120 öğretmen ile gerçekleştirilmiştir. Bu öğretmenlerin 60'1 okul öncesi öğretmeni ve 60'1 sınıf öğretmenidir. Araştırma nicel araştırma yöntemlerinden tarama modelindedir. Araştırmada okul öncesi ve sınıf öğretmenlerinin tükenmişlik düzeylerini belirlemek için Maslach ve Jackson (1981)'ın geliştirdiği Ergin (1992)'in Türkçeye uyarladığı Maslach Tükenmişlik Envanteri; yaratıcılık düzeylerini belirlemek amacıyla Raudsepp (1977)'in geliştirdiği ve Çoban (1999)' in Türkçeye uyarladığı "Ne Kadar Yaratıcısınız? ölçeği uygulanmıştır. Araştırma verileri SPSS 25.0 programından faydalanılarak analiz edilmiştir. Çalışma neticesinde öğretmenlerin genel tükenmişlik ve yaratıcılık puan ortalamaları arasında anlamlı bir ilişki olmadığı görülmüştür. Fakat sınıf öğretmenlerinin genel tükenmişlik puan ortalamalarının ve yaratıcılık puan ortalamalarının okul öncesi öğretmenlerine göre daha yüksek olduğu görülmüştür.
\end{abstract}

Anahtar Kelimeler Sınıf öğretmeni

Okul öncesi öğretmeni

Yaratıclik

Tükenmişlik

Özel okul

Resmi okul

Abstract

Teachers depend on improving students' creative thinking, finding creative solutions to problems, and coping with burnout caused by problems. This study aims to investigate the relationship between creativity and burnout levels of preschool and classroom teachers who work in private and public schools. The study group of this research is comprised of 120 people in total; 60 preschool teachers and 60 classroom teachers teaching in private and public schools in the Nilüfer district of Bursa province in the 2020 and 2021 academic year. The study has been implemented out by means of the scanning model, which is one of the quantitative research methods. In the present study, in an attempt to identify the burnout levels of preschool and classroom teachers, the Maslach Burnout Inventory developed by Maslach and Jackson (1981) and adapted into Turkish by Ergin (1992), and similarly in attempt to determine their creativity levels, the scale titled "How Creative Are You?" developed by Raudsepp (1977) and adapted into Turkish by Çoban (1999) were applied. The SPSS 25.0 program was utilized to analyze the data. It was concluded in the study that there was no significant relationship between the general burnout and creativity scores of the teachers. One other finding, however, in the study was that the general burnout point averages and creativity scores of the classroom teachers were higher than the pre-school teachers.

Keywords

Classroom teacher

Preschool teacher

Creativity

Burnout

Private school

Public school

\begin{tabular}{lll}
\hline Başvuru Tarihi/Received & Kabul Tarihi /Accepted & | Araştırma Makalesi / Research Article \\
01.06 .2021 & 20.10 .2021 &
\end{tabular}

\section{Suggested APA Citation/Önerilen APA Atıf Biçimi:}

Kozan, D., Şahin-Zeteroğlu, E., \& Emeksever, A. (2021). The relationship between creativity and burnout levels of preschool and primary school teachers working in private and public schools. Manisa Celal Bayar University Journal of the Faculty of Education, 9(2), 27-42. https://doi.org/10.52826/mcbuefd.946712.

\footnotetext{
${ }^{1}$ Sorumlu Yazar, Uludağ Üniversitesi, Eğitim Fakültesi, Temel Eğitim Bölümü, Bursa, TÜRKIYE; 2 Uludağ Üniversitesi, Eğitim Fakültesi, Temel Eğitim Bölümü, Bursa, TÜRKIYE; (DD https://orcid.org/0000-0002-2900-7033

3 Sazlıca İlkokulu, Muş, TÜRKIYE; (iD https://orcid.org/0000-0002-3667-335X
} 


\section{GİRIŞ}

Ülkemizde 2005-2006 eğitim-öğretim yılından bu yana yapılandırmacı eğitim uygulanmaktadır. Yapılandırmacı eğitimin uygulanmasındaki başarı, öğretmenlerin ve yöneticilerin bu eğitim yaklaşımı hakkındaki sahip oldukları bilgilere ve uygulayabilmelerine bağlıdır (Şahin, 2010). Yapılandırmacı eğitim temelinde öğrencilerin öğrenme süreci sırasında sorumluluk alarak etkin olmalarına olanak sağlar, iş birliğine ve probleme dayalıdır (Yasar, 1998). Öğrencilerin aktifliği öğretmenin rolünü azaltmamaktadır. Çünkü yapılandırmacı program öğrencilerin bilgiyi keşfetmelerini istemektedir ve eğer öğrenci dikkatli gözlenmezse, doğru yönlendirilmezse hedeflenen kazanımlara ulaşması olanaksız olabilmektedir. Yapılandırmacı eğitimde öğretmenler görevlerinin bilincinde olarak öğrencilerine rehberlik etmelidir (MEB, 2005). Sağlıklı bir toplumun oluşmasındaki en önemli unsur eğitimdir. Bu yüzden eğitim sisteminin etkili şekilde işlerliği olmalıdır. Öğretmen ise bu sistemin temel ögesidir ve diğer öğelere göre sistemi etkileme gücü daha fazladır (Çapa ve Çil, 2000). Öğretmen ne kadar yaratıcı olur, öğrencilerinin yaratıcılıklarını ne kadar dikkate alır ve geliştirmek için ne kadar çabalarsa toplum da o kadar gelişmektedir. Buluşlar yaratıcılık yoluyla ortaya çıkmakta, buluşlar üretim ve teknolojiye dönüşmekte, bu sayede de ekonomik ve toplumsal kalkınma yükselmektedir. Eğer toplumda yaratıcılıkları değerlendirilmemiş, üretim yeteneklerinden yararlanılmamış bireyler varsa o toplumun gelişmesi de zor olmaktadır. Demokratikleşmeye çalışan toplumlar için yaratıcı sorun çözme becerilerinin geliştirilmesi büyük önem taşımaktadır. Eğitim kurumları, bireyleri topluma hazırladıkları, bireylerin yaratıcılığının değerlendirip ve geliştirdikleri için önemli ve bu sebeple toplumsal kalkınmanın vazgeçilmez bir parçasıdır (Şahin, 2003; akt: Erdoğdu, 2005).

"Yaratıcılık" kavramı, hızla gelişen dünyamızda bireylerin yeniye ve farklıya olan ilgi ve ihtiyacının artması ile daha önemli hale gelmektedir. Bu kavram, farklı alanlar ve kişilerce farklı şekillerde tanımlanmaktadır. Tanımlar bazı noktalarda benzer olsalar bile "yaratıcılık" kavramı için tek bir tanımdan bahsetmek mümkün olmamaktadır (Zeytun, 2010). San ve Güleryüz (2004), batı dillerinde 'kreativitaet, creativity' olan yaratıcık Latincede 'creare' olarak geçekte, kelimenin 'doğurtmak, meydana getirmek, yaratmak' anlamlarında olduğunu ve bu anlamlarda dahi dinamik bir sürecin saklı olduğunu belirtmektedir. Argun (2004), yaratıcılığın duygusallığg ve düşünselliği ifade eden bir kavram olduğunu, kendiliğinden oluşmayacağını, cesaretlendirme ve rehberlik ile bir yaşam şekli haline gelebileceğini söylemektedir. Üstündağ (2002), 5N1K sorularının hemen hemen her alanda sorulması ile birlikte yaratıcıllğın, özellikle 20. yüzyıldan günümüze kadarki süreçte akla gelebilecek, tanımlaması oldukça güç olan kavramlardan biri olduğunu vurgulamıştır.

Yaratıcılığın üzerinde etkisi olduğu bilinen pek çok etmen vardır. Bu etmenlerden biri yaştır ve yaratıcllık ile ters orantılı olduğu, yaş ilerledikçe bireylerin yaratıcılıklarının gerilediği yapılan araştırmalarda görülmektedir (Stern ve Robinson, 1998). Bir diğer etmen ise cinsiyettir. Bu noktada toplumsal kültürde kızların ve erkeklerin rollerinin aynı olmaması yaratıcı düşünme becerilerinde de farklılaşma görülmesine sebep olmaktadır (Çetingöz, 2002). Özben ve Argun (2002), yaptıkları araştırmada akıcılık ve esneklik açısından yaratıcılıkta kızların üstün olduğunu belirlemek, özgünlük açısından ise cinsiyetler arası anlamlı bir farklılık bulamamakta; Harmanlı (2002) ise, dil yeteneğinde kadınlar lehine, sayısal yetenekte erkekler lehine sonuçlar ortaya koymaktadır. Başka bir etmen ise sıklıkla yaratıcılık ile karıştırılan zekâdır. Zekâ ve yaratıcılık ayrı kabul edilmektedir fakat orta üstü zekâya sahip bireyler yaratıcılıkta da kendilerini göstermektedir (Şahin-Zeteroğlu, 2015). Başka bir deyiş ile yaratıcılık için belli bir oranda zekâ düzeyinin bulunması gerektiği savunulmaktadır (Gürsoy, 2001). Her alanda yadsınamaz bir güce sahip olan eğitimin, yaratıcılık üzerinde de önemli bir etkisi bulunmaktadır. Bireylerin yaratıcılıklarının ön koşulunun eğitim olduğu düşünülmektedir (Çetingöz, 2002). Vural (2008) da yaratıcılığın doğuştan geldiğini fakat uygun öğretim yöntemleri ile geliştirilebileceğini savunmaktadır. Aile, yaratıcılık üzerinde etkisi olan bir diğer etmendir ve yaratıcılığın temelleri ailede atılmaktadır. Ebeveynlerin tutumlarının (Harmanlı, 2002), ailenin sosyoekonomik düzeylerinin (Gülel, 2006; Kandır, 2001) yaratıcllı üzerindeki etkisi yapılan araştırmalarca ortaya konmaktadır. Saban (2005), yaratıcılığın, aslında bireyin kendisi ve çevresi ile etkileşiminin bir sonucu olduğunu belirtmektedir. Çevrenin de yaratıcılığın ortaya çıkışındaki etkisi göz ardı edilmemelidir. Güvenli ve sürekli

|Manisa Celal Bayar University Journal of The Faculty of Education, 2021, Vol. 9, No. 2| 
uyarıcılar bulunduran bir çevre yaratıcılığı olumlu etkilerken; engellemeler ve sınırlılıkların yaratıcılık üzerindeki etkisi olumsuz olmaktadır (Darıca, 2003).

Yaratıcılığa etkisi olan faktörler olduğu gibi yaratıcılığı engelleyen de pek çok faktör vardır. Bunlar; bireysel engeller, algısal engeller, toplumsal engeller, kültürel engeller, öğrenilen engeller ve yüklü program engelleridir (Şahin, 2010). Bireyler bazen bu engelleri aşabilecek güçte hissetmeyebilmektedir. Yaşam yoğunluğu bireyler üzerinde olumsuz sonuçlara sebep olabilmektedir. Bu sonuçlardan biri tükenmişliktir.

1970'li yıllarda ortaya çıkmaya başlayan tükenmişlik ilk defa 1974 senesinde Herbert Freudenberger tarafından yıpranma, başarısızlık, güç kaybı ve enerji ya da insanın kendi içinde karşılanamayan arzular sebebiyle yaşanan tükenme durumu olarak tanımlanmaktadır (akt: Tatılcı ve Kırımoğlu, 2008). Cherniss (1980)'ye göre ise insanların aşırı stres, doyumsuzluk, mesleğinden soğuma olarak gösterdikleri tepki tükenmişliktir. Tükenmişlik, bağlılığın sonucunda ortaya çıkan bir rahatsızlıktır (akt: Akçamete, Kaner ve Sucuoğlu, 2001). Başaran (2004)’ a göre ise tükenmişlik, genellikle bireylerle yüz yüze çalışılması gereken mesleklerde insanların diğer bireylere duyarsızlaşmaları, duygusal açıdan tükenmiş hissetmeleri, kişisel başarı hissinde ve yeterlilik duygularında eksiklik olarak ortaya çıkan sendromdur. Tükenmişlik üç başlık altında toplanmaktadır. Bunlar duyarsızlaşma, duygusal tükenme ve kişisel başarısı hissidir.

Duyarsızlaşma [depersonalizasyon]: Çalışanlar işinden ya da kendilerinden uzaklaştıklarında, mesleklerine yönelik hedeflerini ve enerjilerini kaybettiklerinde iletişimde oldukları kişilere aldırış etmezler, onlara karşı olumsuz tepkilerde bulunurlar. Bu davranış biçimi duyarsızlaşmanın sonucudur. Duygusal tükenme ve duyarsızlaşma birbiri ile ilişkilidir.

Duygusal tükenme [emotional exhaustion]: Tükenmişliğin en net biçimde görülebilen boyutudur. Bireyler başkalarında gördükleri veya kendilerinde hissettikleri enerji kayıplarını, bitkinliği, yıpranmayı, yorgunluğu bu boyut ile ifade etmektedirler.

Kişisel Başarısı Hissi [personal accomplisment]: Fiziksel ve duygusal açıdan tükenmiş olan bireyler, iletişimde oldukları diğer bireylere ve hatta kendine karşı olumsuz tutum sergilemektedirler. Bu bireyler mesleklerinin sorumluluklarını yerine getirmekte zorlanırlar ve kişisel başarı hisleri azalır (Maslach, Leiter ve Schaufeli, 2001; akt. Gündüz, 2005).

Tükenmişliğin tanımlarından yola çıkarak oluşumunda kişisel nedenlerin ve çevresel nedenlerin etkisi olduğu görülmektedir. Bireyin yaşı, medeni durumu, çocuk sayısı, işine olan bağlılığı, beklentileri, istekleri, kişiliği, performansı, stres durumu, ilişkide olduğu bireyler, gördüğü destek, özsaygı seviyesi kişisel nedenlere dâhil edilebilmektedir. İşinin niteliği, iş yeri, mesai saati, ortamın gürültü durumu, maaş, iş ilişkileri, iş ortamındaki motivasyon ise çevresel nedenler olarak ele alınabilmektedir (Çam, 1992). Tükenmişlik düzeyindeki artış bireylerin içe kapanık, sabırsız, huysuz, hoşgörüsüz olmalarına sebep olmaktadır. Bu durum iş ve aile ortamındaki ilişkileri giderek bozulmaktadır (Torun, 1995).

\section{Problem Durumu}

Bulunduğumuz yüzyıl toplumlar için haberleşme, bilgi, uzay teknolojisi, eğitim, ekonomi gibi alanlarda rekabet ortamı yaratmaktadır. Bütün ülkeler bu rekabet ortamından daha az zararla çıkabilmek, hızlı değişim ve gelişimleri takip edebilmek ve geride kalmamak için sürekli çalışmakta ve yeni teknolojiler üretmektedirler. Eğitim kurumları dünyadaki gelişmelerden en çok etkilenen kurumlardan birisidir. Uluslar, bilgide ileriye gittikçe eğitim kurumlarının yapısında yenilik ihtiyaçları artmıştır. Eğitim ortamına teknolojinin girmesi de eğitimcilerin görev ve rollerinde önemli değişiklikler yapmıştır. Öğretmenlerin eğitim beklentileri farklılaşmış, eğitim anlayışları değişmiştir (Şahin, 2010). Bu da öğretmenlerin iş ilişkilerinden, ekonomik yetersizliklerinden, çalışma ortamlarından, mesleki statülerinden ve okul ortamlarından kaynaklanan problemleri ortaya çıkarmış ve bu problemlerin öğretmenlerde mesleki tükenmişliğe yol açtığı görülmüştür (Yiğit, 2007). Öğretmenin akademik, sosyal ve fiziksel performansını direkt etkileyen bir durum olan tükenmişlik, meslek içinde stres yönetimine uygun 
olmayan davranışlar sergilenmesine sebep olan süreçtir (Sears, Urizar ve Evans, 2000). Bu durum öğretmenlerin yaratıcılıklarını da etkileyebilmektedir.

\section{Araştırmanın Amacı}

Gelecek nesillerin yetiştirilmesinde önemli rolü olan öğretmenlerin sağlıklı ve etkili bir eğitim öğretim sürdürebilmeleri için tükenmişlik durumları, yaratıcılık düzeyleri incelenmeli bu durum eğitim alanındaki uzmanların ve okul yöneticilerinin ele aldığı çalışmalardan biri olmalıdır. Öğretmenlerin tükenmişlik düzeyleri belirlenerek tükenmişliğe sebep olan şartların iyileştirilmesi sağlanabilir. Bu durum öğretmenlerin yaratıcılıklarını da etkileyebilir. Bu da eğitim ve öğretimin daha etkili ve verimli gerçekleşmesini sağlar. Alan yazın incelendiğinde okul öncesi ve sınıf öğretmenleri ile ayrı ayrı yapılmış olan pek çok çalı̧̧maya rastlanılmış olup(Adıgüzel, 2016; Akkurt, 2008; Polat ve Kontaş, 2018; Şahin, 2010; Şenel, 2014; Yılmaz, 2010; Y1lmaz Toplu, 2012) iki grubun yaratıcılık ve tükenmişlik düzeylerinin karşılaştırılmasına dair bir çalışmaya ulaşılamamıştır. Eğitimde, temelin oldukça önemli olduğu göz önüne alındığında yaratıcı bir nesil yetiştirmek için yaratıcı olunması gerektiği düşünüldüğünden okul öncesi ve sınıf öğretmenlerinin yaratıcılığının önemi de yadsınamaz. Bu noktada temel eğitimde görev yapan öğretmenlerin yaratıclık seviyeleri ve yaratıcılığa etkisi olduğu düşünülen tükenmişliğin düzeyi araştııılmalıdır. Bu çalışmanın amacı, Özel ve resmi okulların temel eğitim kademesinde görev yapan öğretmenlerin yaratıcılık ve tükenmişlik düzeyleri arasındaki ilişkiyi ortaya koyarak alan yazına katkı getirmektir.

\section{Araştırmanın Problemi}

Toplumların çağdaş uygarlık seviyesine ulaşabilmesinde eğitim oldukça önemlidir. Eğitimin en önemli unsuru ise şüphesiz ki öğretmenlerdir. Öğretmenlerin çocuklar üzerindeki etkisini bilen toplumun, bu noktada öğretmenlerden beklentisi yüksek olmaktadır. Eğitim sürecinde öğretmenlerin yaratıcı olmasının, rol model oldukları çocukların yaratıcılıklarının gelişmesinde oldukça önemli bir etken olduğu düşünülmektedir. Öğretmenler özveriyle tüm yeterliklerini kullanarak mesleklerini yapmaya gayret gösterirken, bu süreçte pek çok sorunla karşılaşabilmektedirler. Karşılaşılan her sorun öğretmenlerin çalışma isteklerini kaybetmelerine ve mesleki tükenmişlik yaşamalarına neden olabilmektedir. Öğretmenlerin genel tükenmişlik düzeylerinin artmasıyla, yaptıkları mesleğin gerekliliklerini yerine getirmekte zorlandıkları, bu durumun da öğretmenlerin yaratıcılık düzeylerini etkilediği düşünülmektedir.

\section{Araştırmanın Alt Problemleri}

1. Öğretmenlerin yaratıcılık ve tükenmişlik düzeyleri arasında ilişki var mıdır?

2. Öğretmenlerin yaratıcılık ve tükenmişlik düzeyleri ile çalıştıkları kurum türleri arasında ilişki var mıdır?

3. Sınıf öğretmenlerinin yaratıcılık ve tükenmişlik düzeyleri ile çalıştıkları kurum türleri arasında ilişki var midır?

4. Okul öncesi öğretmenlerinin yaratıcılık ve tükenmişlik düzeyleri ile çalıştıkları kurum türleri arasında ilişki var mıdır?

5. Öğretmenlerin tükenmişlik ve yaratıcılık düzeyleri ile demografik özellikleri arasında ilişki var mıdır?

\section{YÖNTEM}

Özel ve resmi okulların temel eğitim kademesinde görev yapan öğretmenlerin genel tükenmişlik düzeyleri ile yaratıcılık düzeyleri arasındaki ilişkinin incelenmesinin amaçlandığı bu araştırmanın modeli, çalışma grubu, veri toplama araçları ve analizi bu bölümde açıklanacaktır.

\section{Araştırma Modeli}

Bu araştırma nicel araştırma yöntemlerinden tarama modelinde yürütülmüştür. Tarama modeli, geçmiş ya da şu andaki durumu olduğu gibi betimleyen modeldir (Karasar, 2010). 


\section{Çalışma Grubu}

Makalenin etik kurul izni, Uludağ Üniversitesi Sosyal ve Beşeri Bilimler Araştırma ve Yayın Etik Kurulu, 2 Ekim 2020 tarihli, 2020-07 sayılı toplantısında alınmıştır. Bu izin doğrultusunda Bursa ili Nilüfer ilçesinde 2020-2021 eğitim-öğretim yılında 30 özel 30 resmi kurumda görev yapan toplam 60 okul öncesi öğretmeni ve 30 özel 30 resmi kurumda görev yapan toplam 60 sınıf öğretmeni olmak üzere toplam 120 öğretmenden veri toplanmıştır. Araştırmanın örneklemi, her bir örneklem birimine eşit derecede seçilme olasılığının verildiği örnekleme yöntemi olan basit seçkisiz örnekleme yöntemiyle oluşturulmuştur. Yani evrendeki tüm bireylerin seçilme olasılı̆̆ı aynı ve birinin seçimi diğerlerinin seçimini etkilememektedir. Her bireyin seçilme şansı eşit ve bağımsızdır (Büyüköztürk, Çakmak, Akgün, Karadeniz ve Demirel, 2014).

Tablo 1. Öğretmenlerin Cinsiyet, Medeni Durum, Sahip Oldukları Çocuk Sayısı, Deneyim, Branş ve Okul Türü Dağılımları

\begin{tabular}{|c|c|c|c|}
\hline \multirow{3}{*}{ Cinsiyet } & & $\mathbf{n}$ & $\%$ \\
\hline & Kadın & 96 & 80,0 \\
\hline & Erkek & 24 & 20,0 \\
\hline \multirow{2}{*}{ Medeni durum } & Evli & 86 & 71,7 \\
\hline & Bekar & 34 & 28,3 \\
\hline \multirow{3}{*}{ Sahip olunan çocuk sayısı } & Yok & 51 & 42,5 \\
\hline & Bir & 31 & 25,8 \\
\hline & İki ve üç & 38 & 31,6 \\
\hline \multirow{4}{*}{ Deneyim } & 1-4 sene & 33 & 27,5 \\
\hline & $5-10$ sene & 39 & 32,5 \\
\hline & $11-15$ sene & 20 & 16,7 \\
\hline & $15+$ sene & 28 & 23,3 \\
\hline \multirow{2}{*}{ Branş } & Sınıf öğretmeni & 60 & 50,0 \\
\hline & Okul öncesi öğretmeni & 60 & 50,0 \\
\hline \multirow{2}{*}{ Okul türü } & Özel Okul & 60 & 50,0 \\
\hline & Resmi Okul & 60 & 50,0 \\
\hline
\end{tabular}

Öğretmenlerin demografik özellikleri incelendiğinde, \%80'inin kadın, \%71,7'sinin evli olduğu, \%42,5'inin çocuğunun olmadığı $1 \% 25,8^{\prime}$ inin bir, \%28,3'ünün iki, \%3,3'ünün üç çocuğu olduğu tespit edilmiştir. Deneyim süreleri incelendiğinde, \%32,5'inin 5-10 yıllık deneyimi olduğu, \%27,5'inin 1-4 yıllık deneyimi olduğu, \%23,3'ünün 15 yıl üzerinde deneyimi olduğu, \%16,7'sinin 11-15 yıllık deneyimi olduğu tespit edilmiştir. Öğretmenlerin \%50'si sinıf öğretmeni, \%50'si okul öncesi öğretmeni, \%50'si özel okul öğretmeni, \%50'si resmi okul öğretmenidir.

\section{Veri Toplama Araçları}

Çalışmada, okul öncesi ve sınıf öğretmenlerinin tükenmişlik düzeylerini tespit etmek için Maslach ve Jackson (1981)'ın geliştirdiği ve Ergin (1992)'in Türkçeye uyarladığı Maslach Tükenmişlik Envanteri kullanılmıştır. Bu envanter toplam 22 maddeden oluşmakta ve tükenmişliği üç boyutta değerlendirmektedir. Duygusal tükenme (Emotional Exhaustion) boyutunda, kişinin mesleği ya da isi tarafından tüketilmiş ve aşırı yüklenmiş olma duygularını ifade eden, 9 madde yer almaktadır. Duyarsızlaşma (Depersonalization) boyutunda, kişinin hizmet verdiklerine karsı duygudan yoksun bir şekilde sergilediği davranışları tanımlayan, 5 madde yer almaktadır. Kişisel başarı (Personal Accomplishment) boyutunda ise isteki yeterlilik ve basarı duygularını ifade eden, 8 madde bulunmaktadır. Maslach Tükenmişlik Envanterinin geçerlik ve güvenirlik çalışması Ergin (1992) tarafından yapılmış ve ölçeğin alt boyutlarına ilişkin test güvenirlik katsayıları duygusal tükenme için .83 duyarsızlaşma için.72 ve kişisel başarı için .67 seklinde bulunmuştur. Maslach Tükenmişlik Envanterini oluşturan duygusal tükenmişlik, duyarsızlaşma ve kişisel başarı alt ölçeklerini oluşturan soru maddelerine verilen 0 - 4 arasında değişen rakamlarla verilen cevaplar, her alt ölçek için ayrı ayrı toplanarak kişinin ilgili alt ölçeklerden aldığı puanlar hesaplanmaktadır. Duygusal tükenme ve duyarsızlaşma alt ölçeğini oluşturan maddeler: 
Hiçbir zaman = 0, Çok nadir = 1, Bazen = 2, Çoğu zaman = 3, Her zaman = 4 seklinde puanlanırken kişisel başarı alt ölçeği ise;

Hiçbir zaman = 4, Çok nadir =3, Bazen = 2, Çoğu zaman =1, Her zaman =0 seklinde puanlanır ve toplam puan elde edilir.

Yaratıcılıklarını belirlemek için ise Raudsepp (1977)'in geliştirdiği ve Çoban (1999)'ın Türkçeye uyarladığı “Ne Kadar Yaratıcısınız?" ölçeği uygulanmıştır. 50 maddeden oluşan ölçek, yaratıcı düşünceye yönelik tutumları ölçen beşli likert tipi bir ölçektir. Bu ölçek, kesinlikle katılıyorum (-2), katılıyorum (-1), kararsızım (0), katılmıyorum (1) ve kesinlikle katılmıyorum (2) seçeneklerinden oluşmaktadır. Ölçek puanları; 100 ile 80 arasında olanların yaratıcılık düzeyleri yüksek, 79 ile 60 arasında olanların yaratıcılık düzeyleri ortalamanın üzerinde, 59 ile 40 arasında olanların yaratıclık düzeyleri orta, 39 ile -20 arasında olanların yaratıcılık düzeyleri ortalamanın altında, -19 ile -100 arasında olanların yaratıcı olmadıkları kabul edilmektedir. Ölçeğin güvenirlik katsayısı Cronbach Alfa; 0.95 bulunmuştur.

\section{Verilerin Analizi}

Veriler SPSS 25.0 programı ile analiz edilmiştir. Normal dağılıma uygunluk, normallik testleri ve basıklık çarpıklık değerleri ile kontrol edilmiştir.

Verilerin analizinde normal dağılım varsayımının sağlanmadığı durumlar tespit edilmiştir. Normal dağılım sağlandığı durumlarda, bağımsız örneklem $t$ testi, normal dağılımın sağlanmadığı durumlarda Mann Whitney U testi, ikiden fazla grup karşılaştırılması için Kruskal Wallis $\mathrm{H}$ testinden faydalanılmıştır. Yapılan testlerin ve sonuçların güvenilir olabilmesi için ölçeklerin güvenilir olması gerekmektedir. Bu bağlamda ölçeklere ilişkin güvenirlikler Cronbach Alpha ile incelenmiştir.

Tablo 2. Ölçeklere İlişkin Güvenirlik Değerleri

\begin{tabular}{ccc}
\hline & & Cronbach's Alfa \\
\hline \multirow{2}{*}{ Tükenmişlik } & Genel Tükenmişlik & 0,867 \\
Alt & Duygusal Tükenme & 0,875 \\
Boyutları & Kişisel Başarı Hissi & 0,733 \\
& Duyarsızlaşma & 0,665 \\
& Yaratıcılık & 0,734 \\
\hline
\end{tabular}

Güvenirlik analizi, ölçeklerde yer alan ifadelerin kendi aralarında tutarlılık gösterip göstermediğini ve ifadelerin tümünün aynı konuyu ölçüp ölçmediğini test etme amacıyla yapılmaktadır (Ural ve Kılıç, 2006: 286). Sonuçlar incelendiğinde, minimum düzeyde ölçeklerin ve alt boyutların "oldukça güvenilir" olduğu tespit edilmiştir.

\section{Araştırmanın Etik İzinleri}

Etik değerlendirmeyi yapan kurul adı: Bursa Uludağ Üniversitesi Araştırma ve Yayın Etik Kurulları Sosyal ve Beşeri Bilimler Araştırma ve Yayın Etik Kurulu

Etik değerlendirme kararının tarihi: 02.10.2020

Etik değerlendirme belgesi sayı numarası: 2020-07

\section{BULGULAR}

Amacı, özel ve resmi okulların temel eğitim kademesinde görev yapmakta olan öğretmenlerin yaratıcılık ve genel tükenmişlik düzeyleri arasındaki ilişkinin incelenmesidir. Bu doğrultuda toplanan veriler ile sonuçları aşağıda tablolar halinde sunulmuştur. 
Tablo 3. Okul Öncesi Öğretmenleri ile Sınıf Öğretmenlerinin Yaratıcılık ve Tükenmişlik Düzeyleri Arasındaki İlişki

\begin{tabular}{|c|c|c|c|c|}
\hline & & & Sınıf Öğretmeni & Okul Öncesi \\
\hline & & & \multicolumn{2}{|c|}{ Yaratıcılık } \\
\hline \multirow{2}{*}{\multicolumn{2}{|c|}{ Genel Tükenmişlik }} & $\mathrm{r}$ & 0,102 & 0,102 \\
\hline & & $\mathrm{p}$ & 0,438 & 0,438 \\
\hline \multirow{6}{*}{$\begin{array}{c}\text { Tükenmişlik } \\
\text { Alt } \\
\text { Boyutları }\end{array}$} & Duygusal Tükenme & $\mathrm{r}$ & 0,019 & $-0,014$ \\
\hline & & $\mathrm{p}$ & 0,887 & 0,917 \\
\hline & Kişisel Başarı Hissi & $\mathrm{r}$ & $0,304^{*}$ & $0,311^{*}$ \\
\hline & \multirow{3}{*}{ Duyarsızlaşma } & $\mathrm{p}$ & 0,018 & 0,016 \\
\hline & & $\mathrm{r}$ & $-0,106$ & $-0,073$ \\
\hline & & $\mathrm{p}$ & 0,419 & 0,582 \\
\hline
\end{tabular}

Okul öncesi öğretmenleri ile sınıf öğretmenlerinin yaratıcılık ve genel tükenmişlik puan ortalamaları arasındaki ilişki Pearson korelasyon analizi ile incelenmiştir. Sonuçlar incelendiğinde hem okul öncesi hem de sınıf öğretmenlerinin genel tükenmişlik ve yaratıcılık puan ortalamaları arasında anlamlı bir ilişki olmadığı (p>0,05), duygusal tükenme ile duyarsızlaşma puan ortalamaları ile öğretmenlerin yaratıcılık puan ortalamaları arasında anlamlı bir ilişki bulunmadığı ( $>00,05)$, sınıf öğretmenlerinin tükenmişlik alt boyutlarından kişisel başarı hissi puan ortalamaları ile yaratıcılık puan ortalamaları arasında pozitif yönlü, anlamlı ve orta seviye bir ilişki olduğu(p<0,05: $\mathrm{r}=0,304$ ), okul öncesi öğretmenlerinin tükenmişlik alt boyutlarından kişisel başarı hissi puan ortalamaları ile yaratıcılık puan ortalamaları arasında anlamlı, pozitif yönlü ve orta seviye bir ilişki olduğu ( $<<0,05: \mathrm{r}=0,311)$, hem okul öncesi hem de sınıf öğretmenlerinin tükenmişlik alt boyutlarından kişisel başarı hissi puan ortalamaları arttıkça yaratıcılık puan ortalamalarının da arttığı görülmüsştür.

Tablo 4. Özel ve Resmi Okullarda Görev Yapan Öğretmenlerin Yaratıcılık ve Tükenmişlik Düzeyleri Arasındaki İlişki

\begin{tabular}{ccccc}
\hline & & & Özel Okul & Resmi Okul \\
\hline & & & \multicolumn{2}{c}{ Yaratıcılık } \\
\hline \multirow{2}{*}{ Genel Tükenmişlik } & $\mathrm{r}$ & 0,232 & 0,063 \\
& & $\mathrm{p}$ & 0,075 & 0,631 \\
\cline { 3 - 5 } & Duygusal Tükenme & $\mathrm{r}$ & 0,156 & $-0,014$ \\
Tükenmişlik & & $\mathrm{p}$ & 0,234 & 0,917 \\
Alt & Kişisel Başarı Hissi & $\mathrm{r}$ & $0,280^{*}$ & $0,332^{* *}$ \\
Boyutları & & $\mathrm{p}$ & $0,030^{*}$ & $0,010^{*}$ \\
& Duyarsızlaşma & $\mathrm{r}$ & 0,036 & $-0,155$ \\
& & $\mathrm{p}$ & 0,783 & 0,237 \\
\hline
\end{tabular}

Özel ve resmi okul öğretmenlerinin yaratıcllık ve genel tükenmişlik puan ortalamaları arasındaki ilişki Pearson korelasyon analizi ile incelenmiştir. Sonuçlar incelendiğinde hem özel okul hem de resmi okul öğretmenlerinin genel tükenmişlik ile yaratıcılık puan ortalamaları arasında anlamlı bir ilişki olmadığı ( $>0,05)$, duygusal tükenme ve duyarsızlaşma puan ortalamaları ile öğretmenlerin yaratıcılık puan ortalamaları arasında anlamlı bir ilişkinin olmadığı ( $>00,05)$, özel okul öğretmenlerinin tükenmişlik alt boyutlarından kişisel başarı hissi ve yaratıcılık puan ortalamaları arasında pozitif yönlü, anlamlı ve zayıf bir ilişki olduğu ( $\mathrm{p}<0,05$ : $r=0,280$ ), resmi okul öğretmenlerinin tükenmişlik alt boyutu olan kişisel başarı hissi ve yaratıcılık puan ortalamaları arasında pozitif yönlü, anlamlı ve orta seviye bir ilişki olduğu ( $p<0,05: r=0,332)$, hem özel okul hem de resmi okul öğretmenleri için kişisel başarı hissi alt boyutu puan ortalamaları arttıkça yaratıcılık puan ortalamalarının da arttığı görülmüştür. 
Tablo 5. Özel ve Resmi Okullarda Görev Yapan Sınıf Öğretmenlerinin Yaratıcılık ve Tükenmişlik Düzeyleri Arasındaki İlişki

\begin{tabular}{|c|c|c|c|c|}
\hline \multicolumn{3}{|c|}{ Sınıf Öğretmeni } & Özel Okul & Resmi Okul \\
\hline \multirow{3}{*}{\multicolumn{2}{|c|}{ Genel Tükenmişlik }} & \multicolumn{3}{|c|}{ Yaratıcılık } \\
\hline & & $\mathrm{r}$ & 0,142 & $-0,20$ \\
\hline & & $\mathrm{p}$ & 0,454 & 0,916 \\
\hline \multirow{6}{*}{$\begin{array}{l}\text { Tükenmişlik } \\
\text { Alt } \\
\text { Boyutları }\end{array}$} & Duygusal Tükenme & $\mathrm{r}$ & 0,088 & $-0,103$ \\
\hline & & $\mathrm{p}$ & 0,646 & 0,589 \\
\hline & Kişisel Başarı Hissi & $\mathrm{r}$ & 0,315 & 0,278 \\
\hline & & $\mathrm{p}$ & 0,090 & 0,137 \\
\hline & Duyarsızlaşma & $\mathrm{r}$ & $-0,108$ & $-0,113$ \\
\hline & & $\mathrm{p}$ & 0,570 & 0,553 \\
\hline
\end{tabular}

Özel ve resmi okullarda görev yapan sınıf öğretmenlerinin yaratıcılık ve genel tükenmişlik puan ortalamaları arasındaki ilişki Pearson korelasyon analizi ile incelenmiştir. Sonuçlar incelendiğinde hem özel okul hem de resmi okulda görev yapan öğretmenlerin genel tükenmişlik puan ortalamaları ile yaratıcılık puan ortalamaları arasında anlamlı bir ilişkinin olmadı̆̆ı görülmüştür $(\mathrm{p}>0,05)$.

Tablo 6. Özel ve Resmi Okullarda Görev Yapan Okul Öncesi Öğretmenlerinin Yaratıcılıkları ve Tükenmişlikleri Arasındaki İlişki

\begin{tabular}{|c|c|c|c|c|}
\hline \multicolumn{3}{|c|}{ Okul Öncesi Öğretmeni } & Özel Okul & Resmi Okul \\
\hline \multirow{3}{*}{\multicolumn{2}{|c|}{ Genel Tükenmişlik }} & \multicolumn{3}{|c|}{ Yaratıcılık } \\
\hline & & $\mathrm{r}$ & 0,327 & $-0,125$ \\
\hline & & $\mathrm{p}$ & 0,077 & 0,511 \\
\hline \multirow{6}{*}{$\begin{array}{c}\text { Tükenmişlik } \\
\text { Alt } \\
\text { Boyutları }\end{array}$} & \multirow[t]{2}{*}{ Duygusal Tükenme } & $\mathrm{r}$ & 0,179 & $-0,222$ \\
\hline & & $\mathrm{p}$ & 0,345 & 0,238 \\
\hline & \multirow[t]{2}{*}{ Kişisel Başarı Hissi } & $\mathrm{r}$ & 0,321 & 0,289 \\
\hline & & $\mathrm{p}$ & 0,084 & 0,121 \\
\hline & \multirow[t]{2}{*}{ Duyarsızlaşma } & $\mathrm{r}$ & 0,204 & $-0,289$ \\
\hline & & $\mathrm{p}$ & 0,280 & 0,121 \\
\hline
\end{tabular}

Özel ve resmi okullarda görev yapan okul öncesi öğretmenlerinin yaratıcılık ve genel tükenmişlik puan ortalamaları arasındaki ilişki Pearson korelasyon analizi ile incelenmiştir. Sonuçlar incelendiğinde hem özel okul hem de resmi okullarda görev yapan okul öncesi öğretmenlerinin genel tükenmişlik puan ortalamaları ile yaratıcılık puan ortalamaları arasında anlamlı bir ilişkinin olmadığı görülmüştür ( $>>0,05)$.

Tablo 7. Öğretmenlerin Yaratıcılık ve Tükenmişlik Düzeylerinin Demografik Özelliklerine Göre Karşılaştırılması

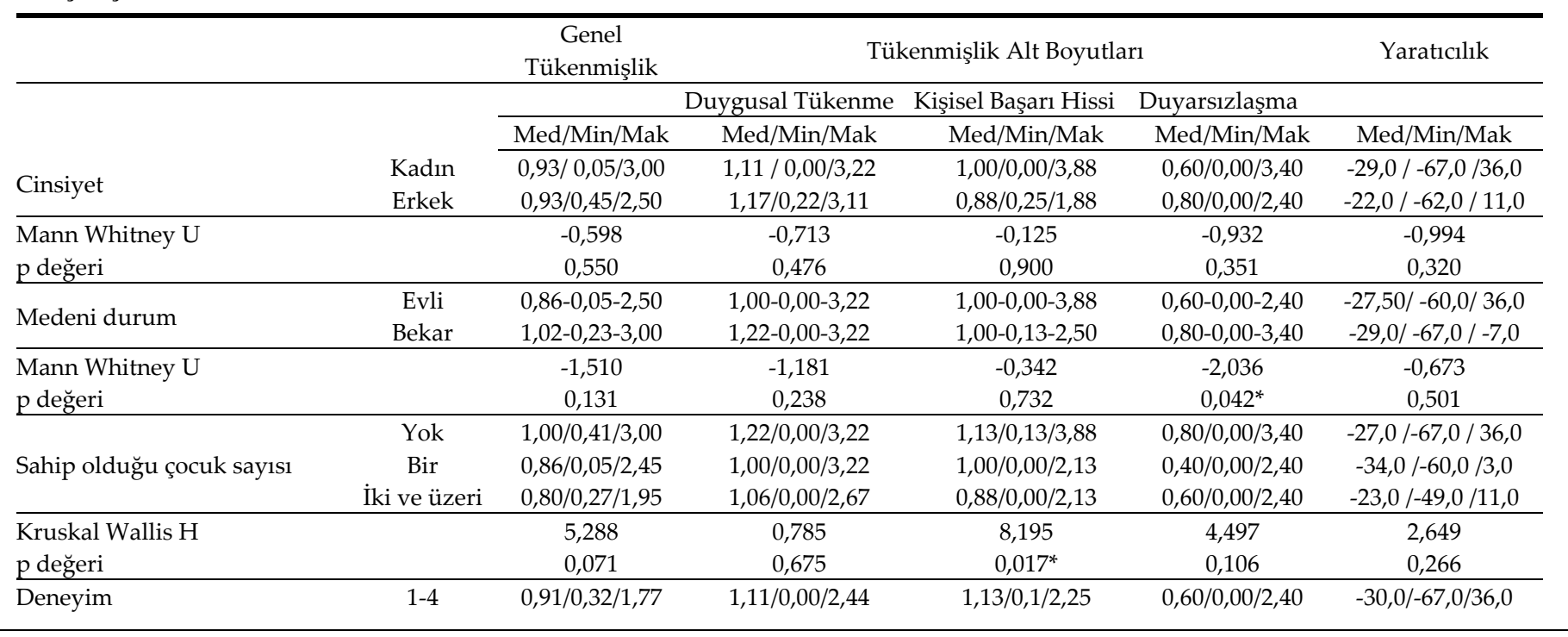

|Manisa Celal Bayar University Journal of The Faculty of Education, 2021, Vol. 9, No. 2 | 


\begin{tabular}{|c|c|c|c|c|c|c|}
\hline & $5-10$ & $0,95 / 0,05 / 2,50$ & $1,11 / 0,00 / 3,11$ & $1,00 / 0,00 / 2,13$ & $0,60 / 0,00 / 2,40$ & $-27,0 /-62,0 / 8,0$ \\
\hline & $11-15$ & $1,05 / 0,36 / 1,95$ & $1,11 / 0,00 / 2,67$ & $0,94 / 0,13 / 3,88$ & $0,60 / 0,00 / 1,80$ & $-31,0 /-60,0 / 2,0$ \\
\hline & $15+$ & $0,84 / 0,23 / 3,0$ & $1,00 / 0,00 / 3,22$ & $0,88 / 0,00 / 2,50$ & $0,60 / 0,00 / 3,40$ & $-21,0 /-58,0 / 11,0$ \\
\hline Kruskal Wallis H & & 1,116 & 1,698 & 3,094 & 0,966 & 5,913 \\
\hline p değeri & & 0,773 & 0,637 & 0,377 & 0,810 & 0,116 \\
\hline \multirow{3}{*}{ Branş } & & $\bar{X} \pm S S$ & $\bar{X} \pm S S$ & $\bar{X} \pm S S$ & $\bar{X} \pm S S$ & $\bar{X} \pm S S$ \\
\hline & Sinif & $11,13 \pm 0,52$ & $1,37 \pm 0,75$ & $1,07 \pm 0,56$ & $0,80 \pm 0,62$ & $-23,47 \pm 17,36$ \\
\hline & Okul öncesi & $0,91 \pm 0,50$ & $0,92 \pm 0,69$ & $1,04 \pm 0,58$ & $0,67 \pm 0,66$ & $-30,75 \pm 13,90$ \\
\hline t testi & & 2,448 & 3,422 & 0,319 & 1,145 & 2,536 \\
\hline $\mathrm{p}$ değeri & & $0,016^{*}$ & $0,001^{*}$ & 0,750 & 0,255 & $0,013^{*}$ \\
\hline \multirow{2}{*}{ Okul türü } & Özel & $0,95 \pm 0,48$ & $0,99 \pm 0,70$ & $1,04 \pm 0,61$ & $0,72 \pm 0,57$ & $-27,38 \pm 16,98$ \\
\hline & Resmi & $1,09 \pm 0,55$ & $1,30 \pm 0,78$ & $1,07 \pm 0,53$ & $0,76 \pm 0,71$ & $-26,83 \pm 15,27$ \\
\hline t testi & & $-1,544$ & $-2,269$ & $-0,279$ & $-0,342$ & $-0,187$ \\
\hline $\mathrm{p}$ değeri & & 0,125 & $0,025^{*}$ & 0,780 & 0,733 & 0,852 \\
\hline
\end{tabular}

Ölçeklerden elde edilen puan ortalamalarının demografik özelliklere göre karşılaştırılma sonuçları Tablo 7' de verilmiştir. Sonuçlar incelendiğinde, öğretmenlerin genel tükenmişlik ve yaratıcılık puan ortalamaları arasında cinsiyete göre anlamlı bir farklılık olmadığı görülmüştür ( $p>0,05)$.

Öğretmenlerin genel tükenmişlik düzeylerinin, duygusal tükenme ve kişisel başarı hissi alt boyutlarının puan ortalamaları ile medeni durumları arasında anlamlı bir farklılık olmadığı ( $>00,05)$, fakat öğretmenlerin duyarsızlaşma alt boyutu puan ortalamaları ile medeni durumları arasında anlamlı bir farklılık olduğu $(p<0,05)$, bekâr olan öğretmenlerin evli olan öğretmenlere göre duyarsızlaşma alt boyutu puan ortalamalarının daha yüksek olduğu, öğretmenlerin yaratıcılık puan ortalamaları ile medeni durumları arasında anlamlı bir farklılık olmadığı görülmüştür ( $\mathrm{p}>0,05)$.

Öğretmenlerin genel tükenmişlik düzeyinin, tükenmişlik alt boyutlarından duygusal tükenme ve duyarsızlaşma puan ortalamaları ile öğretmenlerin sahip olduğu çocuk sayısı arasında anlamlı bir farklılık olmadığı $(p>0,05)$, ancak tükenmişlik alt boyutlarından kişisel başarı hissi puan ortalamaları ile öğretmenin sahip olduğu çocuk sayısı arasında anlamlı bir farklılık olduğu $(p<0,05)$, hiç çocuğu olmayan öğretmenlerin kişisel başarı puan ortalamalarının iki ve daha fazla çocuğu olan öğretmenlerden daha yüksek olduğu, öğretmenlerin yaratıcllık puan ortalamaları ile sahip oldukları çocuk sayısı arasında anlamlı bir farklılık olmadığı görülmüştür. (p>0,05).

Öğretmenlerin genel tükenmişlik ve yaratıcılık puan ortalamaları ile deneyim süreleri arasında anlamlı bir farklılık olmadığ $(p>0,05)$ görülmüştür.

Öğretmenlerin genel tükenmişlik ve tükenmişlik alt boyutu olan duygusal tükenme puan ortalamaları ile branşları arasında anlamlı bir farklılık olmadığı $(p<0,05)$, sınıf öğretmenlerinin genel tükenmişlik puan ortalamalarının, okul öncesi öğretmenlerinin genel tükenmişlik puan ortalamalarından daha yüksek olduğu, fakat kişisel başarı hissi ve duyarsızlaşma alt boyutlarının puan ortalamaları ile öğretmenlerin branşları arasında anlamlı bir farklılık olmadığı ( $p>0,05)$, öğretmenlerin yaratıcılık puan ortalamaları ile branşları arasında anlamlı bir farklılık olduğu $(\mathrm{p}<0,05)$, sınıf öğretmenlerinin yaratıcılık puan ortalamalarının daha yüksek olduğu görülmüştür.

Öğretmenlerin genel tükenmişlik ve tükenmişlik alt boyutlarından kişisel başarı hissi ve duyarsızlaşma puan ortalamaları ile bireyin çalıştı̆̆ı okul türü arasında anlamlı bir farklılık olmadığı ( $>>0,05)$, duygusal tükenme alt boyutu puan ortalamaları ile bireyin çalıştığı kurum türü arasında anlamlı bir farklılık olduğu $(\mathrm{p}<0,05)$, resmi okul öğretmenlerinin duygusal tükenme alt boyutu puan ortalamalarının daha yüksek olduğu, öğretmenlerin yaratıcılık düzeylerinin de çalışılan kurum türüne göre anlamlı bir farklılık göstermediği görülmüştür ( $p>0,05)$.

\section{TARTIŞMA, SONUÇ ve ÖNERİLER}

Yapılan bu çalışmada, öğretmenlerin yaratıcılık ve genel tükenmişlik puan ortalamaları arasında anlamlı bir ilişki olmadığı görülmüştür. Asad ve Khan (2003) da çalışmalarında tükenmişlik boyutları ile yaratıcılık arasında herhangi bir ilişkiye rastlamamıştır. Tükenmişlik ölçeğinin duygusal tükenme ve duyarsızlaşma alt boyutları ile öğretmenlerin yaratıcılık puan ortalamaları arasında anlamlı bir ilişki görülmezken hem okul öncesi hem de sınıf öğretmenleri için tükenmişlik ölçeği alt boyutlarından kişisel başarı hissi puan ortalamaları arttıkça yaratıcılık puan 
ortalamalarının da arttığ1 görülmüştür. Nart (2015) ve Landeche (2009) de çalışmalarında tükenmişliğin sadece kişisel başarı boyutunun yaratıcılık üzerinde etkili olduğunu belirtmişlerdir. Bu etki yönünün tersi olarak, Ghonsoolyi, Raeesi (2012) çalışmalarında, öğretmenlerin yaratıcılıkları arttıkça deneyimledikleri kişisel başarı sıklığının da o kadar yüksek olduğunu belirtmişlerdir. Yaratıcı düşüncelerin kişisel başarıyı, kişisel başarının özgüven ile birlikte yaratıcılığı karşılıklı olarak etkileyeceği yadsınamaz olduğu düşünülmektedir.

Öğretmenlerin genel tükenmişlik ve tükenmişlik alt boyutu olan duygusal tükenme puan ortalamaları ile öğretmenlerin branşları arasında anlamlı bir farklılık olduğu, bunun sonucunda da sınıf öğretmenlerinin genel tükenmişlik puan ortalamalarının okul öncesi öğretmenlerinden yüksek olduğu görülmüştür. Sınıf öğretmenlerinin hedef kitlesinin yaşa bağlı olarak farkındalığının artmasıyla okul öncesi öğrencilere göre öğretilenlerin ve sürecin daha çok farkında olması, ölçme değerlendirmenin ilkokulda ön plana çıkması öğretmenin daha çok çaba sarf etmesine sebep olacağından sonucun bu şekilde olduğu düşünülmektedir. Ancak kişisel başarı hissi ve duyarsızlaşma alt boyutlarından elde edilen puan ortalamaları ile öğretmenlerin branşları arasında anlamlı bir farklılık olmadığı görülmüştür. Yılmaz Toplu (2012)'nun çalışmasında ise, sınıf öğretmenlerinin kişisel başarı hissi alt boyutu puanları, okul öncesi öğretmenlerinin alt boyut puanlarından daha yüksek bulunmuştur. Dolunay ve Piyal (2001) ise çalışmalarında çalışlan okul düzeyi ile öğretmenlerin tükenmişlik düzeyleri arasında anlamlı bir ilişki olmadığını belirtmişlerdir. Öğretmenlerin yaratıcılık puan ortalamaları ile branşları arasında anlamlı bir farklılık olduğu, sını öğretmenlerinin yaratıcılık puan ortalamalarının okul öncesi öğretmenlerinden daha yüksek olduğu görülmüştür. Bunun sebebinin konu ve kazanımların okul öncesi eğitime göre daha çok çeşitlilik göstermesi ve ilkokuldaki not kaygısı sebebiyle öğrenilenlerin kalıcı olması için de öğretmenlerin yaratıcı etkinlikler planlamalarının gerekli olmasından kaynaklanabileceği düşünülmektedir.

Tükenmişlik alt boyutu olan duygusal tükenme puan ortalamaları ile öğretmenlerin çalıştığı kurum türü arasında anlamlı bir farklılık olduğu özel okul öğretmenlerinin duygusal tükenme alt boyutu puan ortalamalarının daha yüksek olduğu görülmüştür. Bu durum resmi okul çalışma imkanlarının özel okullar kadar iyi olamamasının öğretmenlere olumsuz yansıdığı şekilde yorumlanmıştır. Leiter ve Maslach (1988) çalışmasında aşırı iş talepleri gibi çevresel stres faktörlerinin çalışanların duygusal tükenmesine neden olabileceği belirtilmiştir.

Öğretmenlerin genel tükenmişlik ve yaratıcılık puan ortalamaları ile cinsiyetleri arasında anlamlı bir farklılık olmadığı görülmüştür. Bu durum, öğretmenlerin kadın ya da erkek fark etmeksizin, öğretmenlik mesleğinin koşullarında aynı şekilde etkilendiğini düşündürmektedir. Cengizhan (1997), Çiftçi (2002), Çoban (1999) ve Şahin (2010)‘de çalışmalarında yaratıcılık ile cinsiyet arasında anlamlı bir farklılığa rastlamamışlardır. Çimen (2007), Şahin (2008), Urfalı Aksoy (2007) ise çalışmalarında kadınların, duygusal tükenme alt boyut puanlarının erkeklerden daha yüksek olduğu bulunmuştur.

Duygusal tükenme ve kişisel başarı hissi alt boyut puan ortalamaları ile öğretmenlerin medeni durumları arasında anlamlı bir farklılık olmadığı görülmüştür. Ancak, duyarsızlaşma alt boyutunda bekâr öğretmenlerin evli öğretmenlere göre puan ortalamalarının daha yüksek olduğu görülmüştür. Şanlı ve Tan (2017) da yaptıkları çalışmada bekâr öğretmenlerin evli öğretmenlerden daha yüksek duyarsızlaşma ortalamasına sahip olduklarını bulgulamışlardır. Nart (2015) yaptıkları çalışma sonuçları da bu çalışmayı destekler niteliktedir. Bu sonuç, evli öğretmenlerin bekâr öğretmenlerden daha fazla sorumluluğa sahip olmalarının olaylara ve durumlara daha duyarlı yaklaşmalarını sağladığı şeklinde yorumlanabilir. Ayrıca bu durum evli olanların strese karşı daha dayanıklı olduklarını düşündürmektedir. Coyne ve Downey (1991) de iyi bir evliliğin kişiye kazandırdığı dostluk ilişkisi ve sosyal desteğin depresyon riskini azaltmaya yardımcı olduğunu belirtmişlerdir. (akt: Nart, 2015). Alan yazında, Çavuşoğlu (2005), Dolunay (2002), Gündüz (2004), Emlek (2005) ise, tükenmişlik düzeyleri ile medeni durum arasında anlamlı bir ilişki olmadığını belirtmişlerdir. Dilsiz (2006) evli öğretmenlerin kişisel başarı hissi alt boyut puanlarının daha yüksek olduğunu, bekâr öğretmenlerin ise duyarsızlaşma ve duygusal tükenme alt boyutlarında daha yüksek olduğunu belirtmiştir. Kırılmaz, Çelen ve Sarp (2003) da bekâr öğretmenlerin kişisel başarı puanlarının evli öğretmenlere göre daha düşük olduğunu belirtmişlerdir.

|Manisa Celal Bayar University Journal of The Faculty of Education, 2021, Vol. 9, No. 2 | 
Kişisel başarı hissi alt boyut puan ortalamaları ile öğretmenlerin sahip olduğu çocuk sayısı arasında anlamlı bir farklılık olduğu görülmüştür. Hiç çocuğu olmayan öğretmenlerin iki ve daha fazla çocuğu olanlara göre tükenmişlik alt boyutu olan kişisel başarı hissi puan ortalamalarının daha yüksek olduğu görülmüştür. Bu sonuç, çocuğu olmayan öğretmenlerin kendilerine ve mesleklerine ayırdıkları zamanın çocuklu öğretmenlerden daha fazla olabileceği ve bunun da kişisel başarı hislerinin de artmasını sağlayacağı şeklinde yorumlanmıştır. Yılmaz Toplu (2012) ise çalışmasında öğretmenlerin çocuk sayıları ile tükenmişlik alt boyutları puanlarının aritmetik ortalamaları arasında anlamlı bir farklılık gözlenmediğini belirtmiş, bu sonucu öğretmenlerin meslek hayatlarında aile sorunlarına yer vermediklerine yormuştur. Öğretmenlerin yaratıcılık puan ortalamaları ile sahip oldukları çocuk sayısı arasında istatistiksel olarak anlamlı bir farklılık olmadığı görülmüştür.

Öğretmenlerin genel tükenmişlik ve yaratıcılık puan ortalamaları ile deneyim süreleri arasında anlamlı bir farklılık olmadığ görülmüştür. Bu sonuç, deneyimi ne olursa olsun öğretmenlerin olay ve durumlardan aynı düzeyde etkilendikleri şeklinde yorumlanmıştır. Cengizhan (1997), Çoban (1999), Genç (2000), Gürsözlü (2003) çalışmalarında, çalışmamıza benzer olarak deneyim süreleri ile yaratıcılık puanları arasında anlamlı bir farklılığa rastlamamışlardır. Maslach ve Jackson (1981) öğretmenin iş tecrübesinin tükenmişlikle negatif bir ilişki içinde olduğunu ve tecrübesiz öğretmenlerin daha çok tükendiğini çünkü tecrübeleri sayesinde stresle başa çıkma yollarını öğrendiğini belirtmiştir. (akt. Çimen, 2007). Tuğrul ve Çelik (2002) anaokulu öğretmenleriyle, Girgin (1995)'de ilkokul öğretmenleriyle yaptıkları çalışma sonuçlarında ise kıdem yılı arttıkça tükenmişliğin alt boyutu olan kişisel başarı puan ortalamalarının düştüğünü tespit etmişlerdir.

Elde edilen bulgulardan yola çıkarak, öğretmenlik mesleğinin toplumda gerekli saygınlığı kazanmasını sağlayacak çalışmalar yapılabilir. Öğretmenler hem kendi özsaygıların kazanır hem de toplumda saygın olduklarını hissederlerse bu durum onlara yüksek motivasyon sağlayacaktır. Bu saygınlık ile tükenmişlik hissi hafifleyecektir. Ayrıca motivasyona sahip öğretmen yaratıcılık da dahil olmak üzere pek çok becerisini göstermek için istek duyacaktır. Meslek içinde öğretmenler birbirleri ile iletişim halinde olmalı, deneyimlerini birbirleri ile paylaşmalıdır. Bu bir sosyal ağ yardımı ile sağlanabilir. Yönetici desteği oluşturulabilir. Eğitim fakülteleri öğretmen seçimi, eğitimi ve mezuniyeti kriterlerini genişletmeleri için gerekli çalışmaların yapılması sağlanabilir. Öğretmenliğe yeterli görülmeyen bireyler mesleğe yönlendirilmemeli ya da eksikleri noktasında desteklenmelidir. Lisans eğitimi sırasında kişisel gelişimi destekleyen eğitimlere yer verilmeli, bu eğitimler meslek içi eğitim olarak ilerleyen yıllarda devam ettirilmelidir. Bu araştırma daha geniş bir çalışma grubu ile farklı kurum ve kuruluşlarda yapılabilir. 


\section{KAYNAKÇA}

Adıgüzel, D. Ç. (2016). Sınıf öğretmenlerinin yaratıcı düşünme becerileri ile öğretmen davranışlarının öğrencilerin yaratıcı düşünme becerilerinin gelişimine katkısı arasındaki ilişki. (Yayımlanmamış Yüksek Lisans Tezi). Pamukkale Üniversitesi Eğitim Bilimleri Enstitüsü, Denizli.

Akçamete, G., Kaner, S. \& B. Sucuoğlu (2001). Öğretmenlerde tükenmişlik, iş doyumu ve kişilik. Ankara: Nobel Yayın Dağıtım.

Akkurt, Z. (2008). Okulöncesi öğretmenlerinin iş doyumu ve tükenmişlik düzeylerinin incelenmesi (İstanbul-Pendik örneği) (Yayımlanmamış Doktora Tezi). Selçuk Üniversitesi Sosyal Bilimleri Enstitüsü, Konya.

Asad, N., \& Khan, S. (2003). Relationship between job-stress and burnout: organizational support and creativity as predictor variables. Pakistan Journal of Psychological Research, 18(3/4), 139-149.

Başaran, İ. E. (2004). Yönetimde insan ilişkileri. Ankara: Nobel Yayınevi.

Büyüköztürk, Ş., Çakmak, Kılıç, E., Akgün, Ö. E., Karadeniz, Ş. \& Demirel, F. (2014). Bilimsel araştırma yöntemleri (18. baskı). Ankara: Pegem Akademi.

Çam, O. (1992). Tükenmişlik envanterinin geçerlik ve güvenirliğinin araştırılması. VII. Ulusal Psikoloji Kongresi Bilimsel Çalışmaları El Kitabı.

Çapa, Y. \& Çil, N. (2000). Öğretmen adaylarının öğretmenlik mesleğine yönelik tutumlarının farklı değişkenler açısından incelenmesi. Hacettepe Üniversitesi Eğitim Fakültesi Dergisi, 18(18), 69-73.

Cengizhan, S. (1997). Üniversite öğretim elemanlarının yaratıcılık kapasitesinin değerlendirilmesi. (Yayımlanmamış Yüksek Lisans Tezi). Marmara Üniversitesi, Fen Bilimleri Enstitüsü, İstanbul.

Çavuşoğlu, İ. (2005). Endüstri meslek liselerinde çalışan öğretmenlerin tükenmişlik düzeyleri ile bazı kişisel değişkenler arasındaki ilişki (Bolu ili örneği). (Yayımlanmamış Yüksek Lisans Tezi). Abant İzzet Baysal Üniversitesi, Sosyal Bilimler Enstitüsü, Bolu.

Çetingöz, D. (2002). Okul öncesi eğitimi öğretmenliği öğrencilerinin yaratıcı düşünme becerilerinin gelişiminin incelenmesi. (Yayımlanmamış Yüksek Lisans Tezi). Dokuz Eylül Üniversitesi Eğitim Bilimleri Enstitüsü, İzmir.

Çiftçi, Y. (2002). Illköğretim okulu yöneticilerinin yaratıcılık düzeyleri ile liderlik tarzları arasındaki ilişki. (Yayımlanmamış Yüksek Lisans Tezi). Marmara Üniversitesi Eğitim Bilimleri Enstitüsü, İstanbul

Çimen, S. (2007). Illköğretim öğretmenlerinin tükenmişlik yaşantıları ve yeterlik algıları. (Yayımlanmamış Yüksek Lisans Tezi). Kocaeli Üniversitesi Sosyal Bilimler Enstitüsü, Kocaeli.

Çoban, S. (1999). Yöneticilerin yaratıcılık düzeyleri ile liderlik tarzları arasındaki ilişki. (Yayımlanmamış Yüksek Lisans Tezi). İstanbul Üniversitesi Sosyal Bilimleri Enstitüsü, İstanbul.

Darıca, N. (2003). Yaratıcı etkinlikler. İstanbul: Morpa Kültür Yayınları

Dilsiz, B. (2006). Konya ilindeki ortaöğretim okullarında çalışan öğretmenlerin tükenmişlik ve iş doyumu düzeylerinin bölgelere göre değerlendirilmesinin çok değişkenli istatistiksel analizi. (Yayımlanmamış Yüksek Lisans Tezi). Selçuk Üniversitesi, Fen Bilimleri Enstitüsü, Konya.

Dolunay, A. B. (2001). Keçiören ilçesi genel liseler ve teknik-ticaret-meslek liselerinde görevli öğretmenlerde tükenmişlik durumu araştırması. (Yayımlanmamış Yüksek Lisans Tezi). Ankara Üniversitesi.

Dolunay, A. B. Piyal, B. (2001). Öğretmenlerde bazı mesleki özellikler ve tükenmişlik. Kriz Dergisi, 11(1), 35-48.

Emlek, S. (2005). Illköğretim okullarnnda görev yapan yönetici ve öğretmenlerin iş doyum ve mesleki tükenmişlik düzeyleri arasındaki ilişki. (Yayımlanmamış Yüksek Lisans Tezi). Ege Üniversitesi, Sosyal Bilimler Enstitüsü, İzmir.

Erdoğdu, M.Y. (2005). Williams yaratıcılık değerlendirme ölçeği'nin uyarlanması ve yaratıcılık ile algılanan öğretmen davranışları arasındaki ilişki. (Yayımlanmamış Doktora Tezi). Ankara Üniversitesi Eğitim Bilimleri Enstitüsü, Ankara.

Ergin, C. (1992). Doktor ve hemşirelerde tükenmişlik ve Maslach tükenmişlik ölçeğinin uyarlanması. VII. Ulusal Psikoloji Kongresi Bilimsel Çalışmaları. Ankara.

Genç, E. (2000). Ö̆gretmenlerde denetim odă̆ının problem çözmeye yönelik yaratıcllklarıyla ilişkisi. (Yayımlanmamış Yüksek Lisans Tezi). Marmara Üniversitesi Fen Bilimleri Enstitüsü, İstanbul.

Ghonsoolyi B., Raeesi, A. (2012). Exploring the relationship between creativity and burnout among Iranian efl teachers. International Journal of Linguistics 4(3), 121-134. http://dx.doi.org/10.5296/ijl.v4i3.2198

|Manisa Celal Bayar University Journal of The Faculty of Education, 2021, Vol. 9, No. 2 | 
Girgin, G. (1995). İlkokul öğretmenlerinde meslekten tükenmişliğin gelişimini etkileyen değişkenlerin analizi ve bir model önerisi. (Yayımlanmamış Doktora Tezi). Dokuz Eylül Üniversitesi, İzmir.

Gülel, G. (2006). Sınıf öğretmeni adaylarının yaratıcılık düzeylerinin çeşitli değişkenler açısından incelenmesi (Pamukkale Üniversitesi örneği). (Yayımlanmamış Yüksek Lisans Tezi). Pamukkale Üniversitesi Sosyal Bilimler Enstitüsü, Denizli.

Gündüz, B. (2004). Öğretmenlerde tükenmişliğin akılcı olmayan inançlar ve bazı mesleki değişkenlere göre yordanması. (Yayımlanmamış Doktora Tezi). Çukurova Üniversitesi, Sosyal Bilimler Enstitüsü, Adana.

Gündüz, B. (2005). İlköğretim öğretmenlerinde tükenmişlik. Mersin Üniversitesi Ĕ̆itim Fakültesi Dergisi, 1(1), $152-166$.

Gürsoy, F. (2001). Çocukta yaratıcılı̆̆ın gelişimi. Ankara Üniversitesi Ev Ekonomisi Yüksekokulu anaokulu/anasınıfi öğretmen el kitabı. İstanbul: Ya-Pa Yayın Pazarlama.

Gürsözlü, S. (2003). Örgütsel yaratıcılık modelinin oluşmasında bireysel yaratıcılı̆̆ın ve örgüt ikliminin etkisi: reklam ajanslarında bir uygulama. (Yayımlanmamış Yüksek Lisans Tezi). Marmara Üniversitesi Sosyal Bilimler Enstitüsü, İstanbul.

Harmanlı, Z. (2002). Yaratıcılık ve yaratıcılı̆̆ın geliştirilmesinde etkili olan başlıca faktörler. Dokuz Eylül Üniversitesi anaokulu/anasınıfı öğretmen el kitabı. İstanbul: Ya-Pa Yayın Pazarlama.

Kandır, A. (2001). Erken çocukluk eğitiminde kaliteyi belirleyen ölçütler gelişim ve eğitimde yeni yaklaşımlar. İstanbul: Morpa Kültür Yayınları.

Karasar, N. (2010). Bilimsel araştırma yöntemi. Ankara: Nobel Yayın Dağıtım Ltd. Şti.

Kırılmaz, A. Y., Çelen, Ü. \& Sarp, N. (2003). İlköğretimde çalışan bir öğretmen grubunda tükenmişlik durumu. İlköğretim-Online, 2(1), 2-9.

Landeche P. (2009). The correlation between creativity and burnout in public school classroom teachers (Unpublished Master Thesis). University of Southwest Louisiana.

Leiter, M. P., \& Maslach, C. (1988). The impact of interpersonal environment on burnout and organizational commitment. Journal of Organizational Behavior, 9(4), 297-308.

MEB, (2005). Ilköğretim matematik sınıflar öğretim programı kitabı. Ankara: Talim ve Terbiye Kurulu Başkanı.

Nart, S. (2015). Tükenmişliğe etki eden faktörler ve tükenmişliğin yaratıcılık üzerine etkisi: televizyon programları yapımcılığı sektörüne yönelik bir araştırma. (Yayımlanmamış Doktora Tezi). Balıkesir Üniversitesi, Sosyal Bilimler Enstitüsü, Balıkesir.

Özben, S. ve Argun, Y. (2002). Okul öncesi çocuklarının yaratıcı yetenekleri ile anne baba tutumları arasındaki ilişki. Hacettepe Üniversitesi Çocuk Gelişimi ve Ĕ̆itimi Dergisi, 1-14.

Polat, M. \& Kontaş, H. (2018). Sınıf öğretmenlerinin yaratıcılık düzeylerinin incelenmesi. Abant Izzet Baysal Üniversitesi Ĕ̆itim Fakültesi Dergisi, 18(3), 1702-1721.

Raeesi, A. \& Ghonsooly, B. (2012). Creativity, burnout and class dynamism. Lap Lambert Academic Publishing.

Saban, A. (2005). Öğrenme öğretme süreci yeni teori ve yaklaşımlar. Ankara: Nobel Yayın

San, İ. \& Güleryüz, H. (2004). Yaratıcı eğitim ve çoklu zekâ uygulamaları. Ankara: Artım Yayınları.

Stern, S., \& Robinson, A. G. (1998). Cooperative creativity. Berrett Koehler Punlisher Inc.

Üstündağ, T. (2002). Yaratıcılı̆̆a yolculuk. (2. Baskı). İstanbul: PagemA Yayıncılık.

Şahin, S. (2008). Beden eğitimi öğretmenlerinin tükenmişlik ve yaşam doyumu düzeyleri. (Yayımlanmamış Yüksek Lisans Tezi). Mersin Üniversitesi Sağlık Bilimleri Enstitüsü, Mersin.

Şahin, E. (2010). İlköğretim öğretmenlerinde yaratıcılık mesleki tükenmişlik ve yaşam doyumu. (Yayımlanmamış Yüksek Lisans Tezi). Sakarya Üniversitesi Sosyal Bilimler Enstitüsü, Sakarya.

Şahin-Zeteroğlu, E. (2015). Erken çocukluk döneminde yaratıcılık ve geliştirilmesi (4. Baskı). Ankara: Pegem Akademi

Şanlı, Ö. \& Tan, Ç. (2017). Öğretmenlerin tükenmişlik düzeylerinin çeşitli değişkenler açısından incelenmesi. Fırat Üniversitesi Sosyal Bilimler Dergisi, 27(2), 131-142.

Şenel, E. (2014). Okul öncesi öğretmenlerinde özyeterlik algısının tükenmişlik düzeyini yordama gücü: Denizli ili örneği. (Yayımlanmamış Yüksek Lisans Tezi), Pamukkale Üniversitesi Eğitim Bilimleri Enstitüsü, Denizli.

Tatılcı, M. \& Kırımoğlu H. (2008). Atletizm Antrenörlerinin mesleki tükenmişlik düzeylerinin incelenmesi. Niğgle Üniversitesi Beden Eğitimi ve Spor Bilimleri Dergisi, 2(1), 34-47. 
Torun, A. (1995). Tükenmişlik, aile yapısı ve sosyal destek ilişkileri üzerine bir inceleme. (Yayımlanmamış Doktora Tezi). Marmara Üniversitesi, İstanbul.

Tuğrul, B. \& Çelik, E. (2002). Normal çocuklarla çalışan anaokulu öğretmenlerinde tükenmişlik. Pamukkale Üniversitesi Ĕ̆itim Fakültesi Dergisi, 2(12), 1-11.

Ural, A. \& Kılıç, İ. (2006). Bilimsel araştırma süreci ve SPSS ile veri analizi. (Genişletilmiş İkinci Baskı), Ankara: Detay Yayıncilı.

Urfalı Aksoy, S. (2007). Eskişehir ili özel eğitim kurumlarında çalışan öğretmenlerin tükenmişlik düzeylerinin değerlendirilmesi. (Yayımlanmamış Yüksek Lisans Tezi). Eskişehir Osmangazi Üniversitesi Sağlık Bilimleri Enstitüsü, Eskişehir.

Vural, T. C. (2008). Sosyal bilgiler eğitiminde yaratıcı düşünme: yeni ilköğretim programı besinci sınıf sosyal bilgiler öğretiminde kullanılan etkinliklerin yaratıcılı̆̆ı geliştirmesi açısından değerlendirilmesi. (Yayımlanmamış Yüksek Lisans Tezi). Çukurova Üniversitesi Sosyal Bilimler Enstitüsü, Adana.

Yaşar, S. (1998). Yapısalcı kuram ve öğrenme-öğretme süreci. Anadolu Üniversitesi Eğitim Fakültesi Dergisi, 8(2), 68-75.

Yılmaz, B. (2010). Özel ve resmi ilköğretim okullarındaki sınıf öğretmenlerinin tükenmişlik düzeylerinin incelenmesi. (Yayımlanmamış Yüksek Lisans Tezi). Uludağ Üniversitesi, Eğitim Bilimleri Enstitüsü, Bursa.

Yılmaz Toplu, N. (2012). Okul öncesi ve ilköğretim öğretmenlerinin tükenmişlik düzeyleri. (Yayımlanmamış Yüksek Lisans Tezi) Adnan Menderes Üniversitesi, Sosyal Bilimler Enstitüsü, Aydın.

Yiğit, A. (2007). Özel eğitim kurumlarında çalşan öğretmenlerin iş doyumu, tükenmişlk ve ruh sağllk düzeylerinin çeşitli değişkenler açısından incelenmesi. (Yayımlanmamış Yüksek Lisans Tezi). Niğde Üniversitesi Sosyal Bilimler Enstitüsü, Niğde.

Zeytun, S. (2010). Okul öncesi öğretmenliği öğrencilerinin yaratıcllk ve problem çözme düzeyleri arasındaki ilişkinin incelenmesi. (Yayımlanmamış Yüksek Lisans Tezi). Dokuz Eylül Üniversitesi, İzmir. 


\section{Extended Abstract}

\section{Introduction}

Education is very important for societies in an attempt to attain the level of modern civilization. Categorically, the teachers are the most important element of education. At this point, any society that comprehends the effect of teachers on children has high expectations from teachers. It is commonly believed that the creativity of the teachers as role models in the education process is a very vital element in the development of the children's creativity. While teachers try to perform their profession by utilizing all their competencies with devotion, they may encounter many problems throughout this process as well. Every problem encountered can cause teachers to lose their motivation to perform and experience professional burnout. It is goes without saying that as the general burnout level of teachers' increases, they come to find it difficult to fulfill the requirements of their profession, and this situation, in turn, affects the creativity levels of teachers.

The concept of "creativity" becomes all the more important in our rapidly developing world with the increasing interest and need of individuals for the new and different. This concept is defined differently in different fields by different scholars. Even though there some similarities in these definitions to a certain extent, one cannot to talk about a single definition for the concept of "creativity" (Zeytun, 2010). San and Güleryüz (2004) states that the creativity, which is 'creativitaet, creativity' in western languages, is referred to as 'creare' in Latin, and that the word means 'to give birth, to produce, to create' and even in these meanings a dynamic process is hidden. Argun (2004) states that creativity is a concept that expresses emotionality and intellectuality, that it cannot occur spontaneously, and that it can become a lifestyle with encouragement and guidance. Üstündağ (2002) emphasizes that creativity is one primary concept that springs to mind especially in the period starting from the 20th century till the present time and has been very difficult to define, with 5W1K questions being asked in almost every field.

The idea of burnout, which started to emerge in the 1970s, was initially described by Herbert Freudenberger in 1974 as a state of exhaustion due to wear, failure, loss of power and energy or desires that cannot be met within the human being (cited in Tatılcı and Kırımoğlu, 2008). According to Cherniss (1980), the reaction people display as excessive stress, dissatisfaction, and getting out of their profession is actually burnout. Burnout is a disorder that occurs as a result of commitment (cited in Akçamete, Kaner, \& Sucuoğlu, 2001). According to Başaran (2004), burnout is a syndrome that happens as a feeling of insensitivity to other individuals, feeling emotionally exhausted, a lack of personal accomplishment and a sense of competence in professions that require individuals to work face to face. It is possible to group the idea of burnout under three headings: These are emotional exhaustion, depersonalization, and a sense of personal accomplishment.

Emotional exhaustion: This is the utmost noticeably visible dimension of burnout. People talk about the loss of energy, exhaustion, weariness and fatigue that they see in others or feel in themselves within this dimension.

Depersonalization: When employees move away from their jobs or themselves, lose their professional goals and energy, they ignore the people they are in contact with and react negatively towards them. This behavior is the result of desensitization. Emotional exhaustion and depersonalization are interrelated.

Personal accomplishment: Individuals who are physically and emotionally exhausted display a negative attitude towards others and even themselves. These individuals suffer from difficulties in fulfilling the responsibilities of their profession and their sense of personal accomplishment declines (Maslach, Leiter, \& Schaufeli, 2001; cited in Gündüz, 2005).

In order for teachers, who have an important role in raising future generations, to maintain a healthy and effective education, their burnout and their level of creativity should be examined, and this should be one of the studies addressed by experts in the education field and school administrators. The conditions that cause burnout can be improved by identifying the burnout levels of teachers. This situation can also impact teachers' creativity. This makes education and training more effective and efficient. When the literature is examined, many studies that have been done separately with preschool and classroom teachers were found (Akkurt, 2008; Şahin, 2010; Yılmaz, 2010; 
Yılmaz Collective, 2012; Şenel, 2014; Adıgüzel, 2016; Polat \& Kontaş, 2018) There is no study available that compares the creativity and burnout levels of the two groups. Present study aims to make a contribution to the relevant literature by identifying the relationship between the creativity and burnout levels of preschool and classroom teachers who work in public and private schools.

\section{Method}

The scanning model, which is one of the quantitative research methods, is the method utilized in the present study. Scanning model is a model that describes the past or current available situation (Karasar, 2010).

In the present study, data came from a total of 120 teachers, including 60 preschool teachers who worked in 30 private and 30 private public schools and a total of 60 classroom teachers who worked in 30 private and public institutions in the 2020 and 2021 academic year in the Nilüfer district of Bursa province. The study sample was obtained by the method of simple random sampling. This particular method is the sampling method in which each sampling unit is given an identical likelihood of selection. In other words, the likelihood of selection for all individuals in the universe is the same and, choosing a particular one does not impact the choice of others. The chance of being selected for each individual is equal and independent (Büyüköztürk, Çakmak, Akgün, Karadeniz, \& Demirel, 2014).

In the present study, in an attempt to identify the burnout levels of preschool and classroom teachers, the Maslach Burnout Inventory developed by Maslach and Jackson (1981) and adapted into Turkish by Ergin (1992), and similarly in attempt to determine their creativity levels, the scale titled "How Creative Are You?" developed by Raudsepp (1977) and adapted into Turkish by Çoban (1999) were applied. The SPSS 25.0 program was utilized in order to analyze the data. Conformity to normal distribution was checked with normality tests and kurtosis and skewness values.

\section{Findings, Result and Discussion}

Based on the results obtained from the data analysis, it is possible to conclude that no statistically significant relationship emerged between the general burnout levels of the teachers and their level of creativity. However, the creativity of preschool and classroom teachers who taught in private and state schools increased as their personal accomplishment scores from burnout sub-dimensions increased. In addition, as the number of children that teachers have, their personal accomplishment scores increase. It was found that depersonalization scores of single teachers were higher than teachers who were married. Classroom teachers' general burnout levels, emotional exhaustion levels from burnout sub-dimensions and levels of creativity were higher than the preschool teachers. It was also found that the emotional exhaustion levels of teachers teaching in public schools were higher than those of teachers' teaching in private schools.

\section{Araştırmanın Etik İzinleri}

Yapılan bu çalışmada "Yükseköğretim Kurumları Bilimsel Araştırma ve Yayın Etiği Yönergesi” kapsamında uyulması belirtilen tüm kurallara uyulmuştur. Yönergenin ikinci bölümü olan “Bilimsel Araştırma ve Yayın Etiğine Aykırı Eylemler" başlı̆̆ altında belirtilen eylemlerden hiçbiri gerçekleştirilmemiştir.

Etik değerlendirmeyi yapan kurul adı: Bursa Uludağ Üniversitesi Araştırma ve Yayın Etik Kurulları Sosyal ve Beşeri Bilimler Araştırma ve Yayın Etik Kurulu

Etik değerlendirme kararının tarihi: 2 Ekim 2020

Etik değerlendirme belgesi sayı numarası: 2020-07 